\title{
From cultural activity to cultural tourism: a case of indigenous community in Malaysia
}

\begin{abstract}
Indigenous communities in Malaysia comprise of many tribes which practices different believes and culture. Although they are minorities which represent approximately $12 \%$ or the country population, their culture managed to attract attention from domestic and international tourists due to its uniqueness of it. Majority of Malaysia's indigenous communities live in East Malaysia. They are called Orang Ulu or Dayak in Sarawak, and in Sabah, they are called Anak Negeri, while in West Malaysia, there are three major indigenous communities identified or better known as Orang Asli. These three groups are as follows: Semang, Senoi, and Proto-Malay. The general objective of this study was to look at the traditional culture of Malaysia's indigenous communities in West Malaysia that have significant potential in attracting tourists. Three tribes have been identified by this study, which are Che Wong, Mah Meri, and Temuan. The usage of their traditional culture for tourism activities has been investigated. For the first initial stage, personal face-to-face interview with the stakeholders and Orang Asli community have taken place at their villagers. This will assist this study in designing questionnaire in the next stage. The result shows that all three tribes have been engaged actively in tourism activities.
\end{abstract}

Keyword: Culture; Indigenous communities; Orang Asli; West Malaysia 